\title{
The health of children and adolescents in foster care: a scoping review
}

\author{
A saúde de crianças e adolescentes em acolhimento institucional: uma revisão de escopo \\ La salud de los niños y adolescentes en atención institucional: a scoping review
}

Received: 09/24/2021 | Reviewed: 10/03/2021 | Accept: 10/04/2021| Published: 10/05/2021

Gabriela Brito Vasconcelos

ORCID: https://orcid.org/0000-0002-5342-542X University of Pernambuco, Brazil

E-mail: gabriela.vasconcelos@upe.br

Nataly Pereira da Costa

ORCID: https://orcid.org/0000-0002-5585-8392

University of Pernambuco, Brazil

E-mail: nataly.pcosta@hotmail.com

Alice Kelly Barreira

ORCID: https://orcid.org/0000-0002-0351-9022

Federal University of Pernambuco, Brazil

E-mail: alice.kelly@ufpe.br

Viviane Colares

ORCID: https://orcid.org/0000-0003-2912-2100

University of Pernambuco, Brazil

Federal University of Pernambuco, Brazil

E-mail: viviane.colares@upe.br

\begin{abstract}
Providing healthcare to foster minors is challenging, given the family and institutional risk factors. This scoping review aimed to identify characteristics of articles on these minors' health, published in PubMed from 2010 to 2020 , following the Joanna Briggs model. The research question was developed with the PCC acronym. Half of the 252 articles were from the United States; most were from the Health Sciences, then multidisciplinary ones, and from the Human Sciences. Under Health, Medicine published the most, then Dentistry, Public Health, Nursing, Nutrition, and Pharmacy. Psychology represented the Human Sciences. In Medicine, there were studies from Pediatrics, Psychiatry, Endocrinology, and Parasitology. The participation of Pediatrics, Psychology/Psychiatry, and Dentistry increased over time. The types of care (of which, foster care and child welfare system were the most prevalent) associated with continents, reflecting a deinstitutionalization in America, Europe, and Oceania. The most approached health topics were mental, physical, and oral health, and the need for health services. The increased number of health publications, predominantly in developed countries and addressing various problems, confirms this group's vulnerability, evidencing the need for public policies.
\end{abstract}

Keywords: Children; Adolescent; Foster home care; Health status; Child foster.

\section{Resumo}

Os fatores de risco da família e instituição geram desafios para a saúde de menores em acolhimento. Esta revisão de escopo objetivou identificar características de artigos sobre a saúde desses menores, publicados de 2010 a 2020 em PubMed, seguindo o modelo do Joanna Briggs Institute. A pergunta norteadora foi construída pelo acrônimo PCC. Metade dos 252 artigos era dos Estados Unidos; a maioria era das Ciências da Saúde, seguido dos multidisciplinares e das Ciências Humanas. Em Saúde, Medicina foi a que mais publicou, seguida de Odontologia, Saúde Pública, Enfermagem, Nutrição e Farmácia; e em Humanas, a Psicologia. Na Medicina, observou-se Pediatria, Psiquiatria, Endocrinologia e Parasitologia. Houve crescente participação da Pediatria, Psicologia/Psiquiatria e Odontologia. Houve associação entre os tipos de cuidado (dos quais, os mais prevalentes foram foster care e child welfare system) e continentes, refletindo a desinstitucionalização na América, Europa e Oceania. Os temas de saúde mais abordados foram saúde mental, física e bucal e necessidade de serviços de saúde. O aumento de publicações na saúde, com predominância de países desenvolvidos e abordagem de diversos problemas, confirma a vulnerabilidade desse grupo, revelando a necessidade de políticas públicas.

Palavras-chave: Criança; Adolescente; Cuidados no lar de adoção; Condições de saúde; Criança acolhida.

\section{Resumen}

Los factores de riesgo de la familia y la institución crean desafíos para la salud de los menores en cuidado. Esta revisión de alcance tuvo como objetivo identificar las características de los artículos sobre la salud de estos menores, publicados de 2010 a 2020 en PubMed, siguiendo el modelo del Instituto Joanna Briggs. La pregunta guía fue construida por el acrónimo PCC. La mitad de los 252 artículos eran de Estados Unidos; la mayoría eran de las 
Ciencias de la Salud, seguidas de las multidisciplinarias y las Ciencias Humanas. En Salud, Medicina fue la que más publicó, seguida de Odontología, Salud Pública, Enfermería, Nutrición y Farmacia; y en Humanos, Psicología. En Medicina, Pediatría, Psiquiatría, Endocrinología y Parasitología se observaron. Hubo una participación creciente de Pediatría, Psicología / Psiquiatría y Odontología. Hubo una asociación entre los tipos de cuidado (de los cuales los más prevalentes fueron el sistema de acogimiento familiar y el sistema de bienestar infantil) y los continentes, lo que refleja la desinstitucionalización en América, Europa y Oceanía. Los temas de salud más discutidos fueron la salud mental, física y bucal y la necesidad de servicios de salud. El incremento de publicaciones en salud, con predominio de países desarrollados y atendiendo diversos problemas, confirma la vulnerabilidad de este grupo, revelando la necesidad de políticas públicas.

Palabras clave: Niño; Adolescente; Cuidados en el hogar de adopción; Estado de salud; Niño acogido.

\section{Introduction}

The unfavorable health conditions of children and adolescents in foster care have been widely approached in countless studies. Such problems have proved to persist into early adulthood and early middle age, robustly influencing their life expectancy (Almquist et al., 2018). Foster care services are expected to provide children and adolescents subject to family crises with temporary shelter, healthcare, security, belonging, and well-being. Moreover, they should develop their skills, strengthen the ties with their original families, and provide the biological parents with all the necessary means to reunite and bond with their children. On the other hand, foster care also poses potential risks due to the complexity involving the care for this population. In this regard, both intervention and observational studies are important to address the challenge of meeting the needs of children and adolescents in foster care.

Such children and adolescents belong to unfavored or socially marginalized groups, whose disease burden is high (United Nations International Children's Emergency Fund [UNICEF], 2017). They have a high prevalence of chronic diseases, developmental deficiencies, educational disorders, dental problems, and behavioral, emotional, and mental health problems (Szilagyi, 2012). They are normally put out of their home because of accumulated and varied psychosocial risk factors, such as living in a dysfunctional family and/or being exposed to different forms of maltreatment (Greger, Myhre, Lydersen, \& Jozefak, 2015; Wolkind \& Rutter, 1973). Furthermore, young people in foster care are at greater risk of using substances (Casanueva, Stambaugh, Urato, Fraser, \& Williams, 2011; Gabrielli, Jackson, \& Brown, 2016). Another important aspect is their quality of life, which may be negatively influenced by various factors (Gander et al., 2019).

There are different types of foster care services throughout the world, as there are different laws in each country. Hence, they range from small temporary units to large institutions. Therefore, a variety of terms is used to refer, sometimes interchangeably, to foster care services: "institution", "children's home", "group care facility", "residential treatment unit", "foster care", "infant care institutions", "child care institutions", "short-term therapeutic institutions", "group homes for independent living", and "family homes" (Ainsworth \& Thoburn, 2014; Human Rights Watch [HRW], 2014).

Accordingly, the different names characterize the various types of foster care, classified by UNICEF and Eastern Europe and the Commonwealth of Independent States (CEE/CIS) (2010), as either formal or informal care. The type of foster care into which children are put noticeably influences their rates of emotional and behavioral disorders (Naylor, Wakefield, Morgan, \& Aneja, 2019). Nevertheless, there are diverging data regarding the onset of problems in children under family care and other nonparental care (Szilagyi, 2012).

The context to which children and adolescents in foster care belong is one of extreme vulnerability, which makes such an approach greatly relevant to the field of health - particularly, considering the worldwide variety of foster care systems. Therefore, it is greatly important to carry out a global analysis of what is being studied in the literature. The different approaches to the topic from the many fields of study, with their various characteristics, similarities, and differences through time, are essential to understand the population in foster care. Knowledge of such information can promote broader discussion, help standardize methodologies, and increase the level of evidence of research on this topic. This study is a scoping review 
whose aim is to analyze the characteristics of the scientific publications on the health of children and adolescents in foster care.

\section{Materials and Methods}

\section{Type of study}

The objective of a scoping review of the literature is to survey what has been published about a given topic that sustains a research field. It enables to assess the development, variety, and characteristics of the extant evidence in the literature regarding an issue or topic, summarizing the related knowledge. Thus, we can answer broad questions, track information, and furnish an overall view of the evidence found, helping administrators in decision-making (Foxcroft \& Tsertsvadze, 2011) (Peters et al., 2015). Moreover, as it identifies gaps in the research, it can be used to formulate evidencebased recommendations for further research (Peters et al., 2015; Tricco et al., 2018).

\section{Methodological procedures}

We used the protocol published by Peters et al. (2015), developed by members of the Joanna Briggs Institute (JBI) (2015), and adopted the following scoping review stages: developing the title, objectives, and research question; establishing the inclusion and exclusion criteria for the studies; selecting the data sources; collecting and organizing the results; and presenting the review.

We also used the Preferred Reporting Items for Systematic Reviews and Meta-Analyses - Extension for Scoping Reviews (PRISMA-ScR) guidelines (Tricco et al., 2018). Two independent researchers, who had been previously instructed and calibrated by a third experienced one, conducted the procedures of the review. In case of disagreement on whether to include an article, a consensus meeting was held (Kappa $=0.77)$.

\section{Research question}

The research question was developed based on the Population, Concept, Context (PCC) methodology, proposed by the JBI protocol (Peters et al., 2015). In this study, the Population is children and adolescents, the Concept is their health, and the Context is foster care. The resulting research question is: "What are the characteristics of the scientific publications on the health of children and adolescents in institutional foster care?"

\section{Selection of the data sources}

We searched for articles in the MEDLINE database via PubMed, encompassing those designed as original research, literature reviews, practical guides, letters/reports, or theoretical reflections approaching the health of children and adolescents in foster care. This database was selected because of its multidisciplinary scope and coverage in the field of health.

\section{Search strategy}

We conducted a broad search strategy in the database from July to August 6,2020, constructing it with the following descriptors and their combinations with the Boolean operators AND and OR: Child; adolescent; child, foster; foster home care; group homes; orphanages; child, orphaned; child, institutionalized; adolescent, institutionalized; institutionalization; health status; oral health (as MeSH terms). Youth; foster child; foster care; foster caregivers; foster youth; children's residential homes; residential care; placement in care; kinship care; out-of-home care; orphanage; children orphaned; adolescent orphaned; institutionalized child; institutionalized adolescent; institutionalized person; institutionalized population; institutional care; institutional rearing (as Title/Abstract).

We filtered the search by publication year (10 years) and language (English, Portuguese, and Spanish). 


\section{Inclusion and exclusion criteria}

All types of publications on the health of children and adolescents in foster care were considered.

To define inclusion, the concept of children and adolescents in foster care was those sheltered by some institutional foster care services. Institution, a term present in the studies to refer to the types of child and adolescent foster care services, is broadly used in policy and program planning documents to refer to homes in which children from various families live with biologically unrelated caregivers. Other types of institutions were excluded, such as the comprehensive psychiatric and hospital ones for patients with disabilities, who despite having a family cannot be cared for at home. We also excluded the young offender institutions.

We also considered all the modalities of foster care service, classified as either formal or informal care, ranging from small homes with long-term co-residing caregivers to large facilities with many family-like unities, such as kinship care, orphanage, children's home, group care facility, residential treatment unit, foster care, children's residential homes, out-ofhome care, residential care, institutional care, institution, institutional rearing, group homes, placement in care. Furthermore, we considered the orphans, referred to as children and adolescents living in some form of foster care who have lost at least one of their parents or who have been abandoned by both parents and they are not expected to return and/or cannot be contacted.

\section{Data collection and organization}

The articles were selected in two stages: (1) reading the titles and abstracts and (2) reading the full text.

Firstly, we entered the results into a table in Word®, listing the studies in columns by author and year, based on manual search, and classifying them as either included or excluded by title and abstract (with the reason for exclusion). The articles screened to be read in the full text were then entered into an Excel® document, extracting from them the following data: author, year, country, keywords, broad field of knowledge, subfield of health, health topic, type of institutional care, sample (n), sample (age), and publication type. We also noted possible exclusions in this phase. All the stages in the search and selection process are described in Figure 1. 
Figure 1 - Flowchart of the PRISMA-ScR article search and selection process.
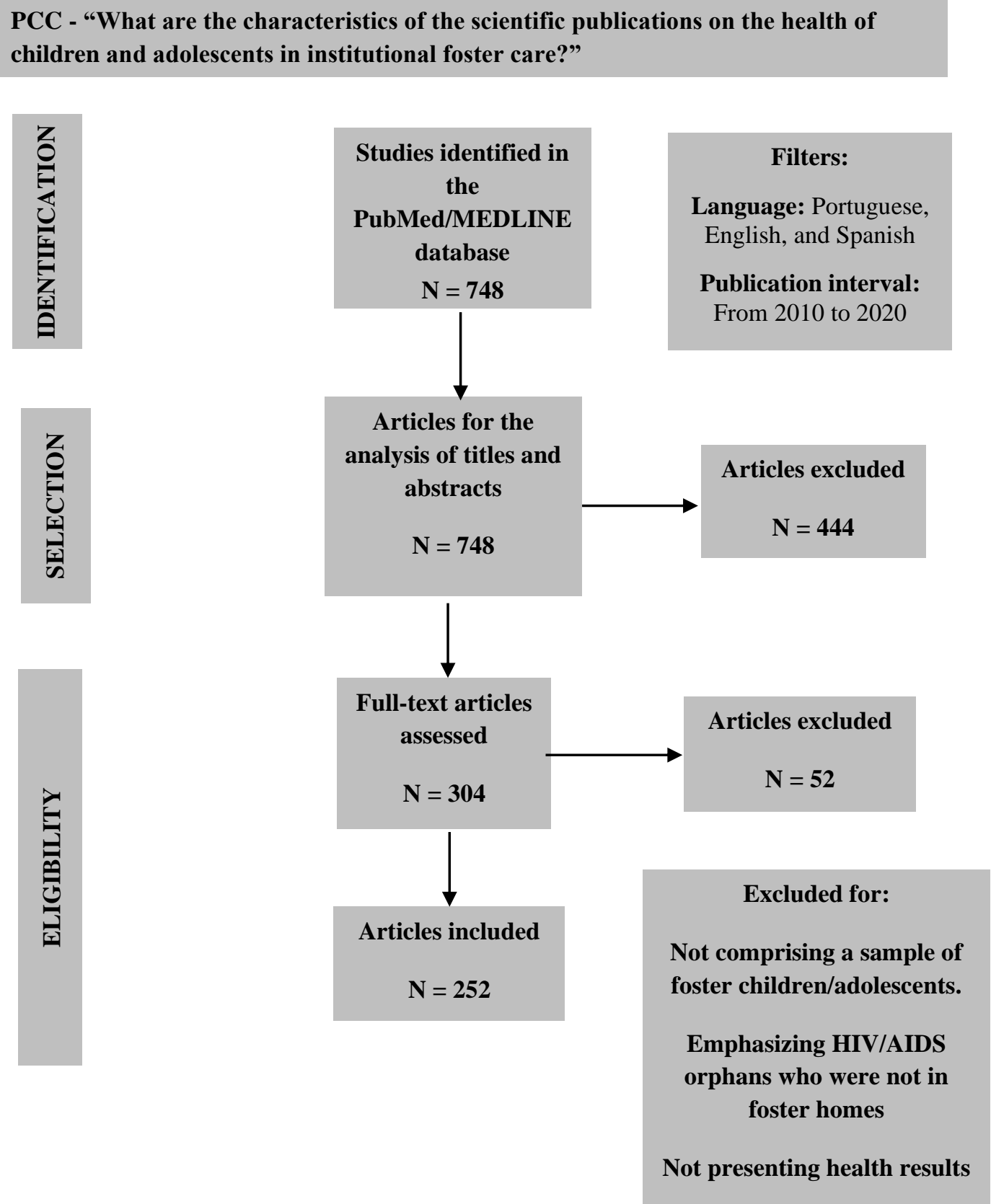

Source: Authors.

\section{Data analysis}

We analyzed the data descriptively with absolute and percentage frequencies. Opportunely, we also assessed the association between two categorical variables to deepen the topic. We used Pearson's chi-square test, or Fisher's exact test when the conditions to use the chi-square were not met. The 5\% significance level was used in decision-making in the statistical tests. The statistical calculations were made in the IBM SPSS, version 25. We used a word cloud (https://www.abcya.com/games/word_clouds) to identify keywords in the publications and a word count (http://rotasul.net/c- 
tools/textoconta) for their recurrence and frequency. The same programs were used to identify and analyze the recurrence and frequency of the health topics approached.

\section{Results}

The data, collected and categorized under publication year, type, continent of origin, broad field of knowledge, subfields of health that originated the publications, types of institutional foster care, and sample size and age, are shown in Table 1.

Regarding their publication year, the comparison between the two halves of the decade in question revealed an increase in the number of articles.

Almost all the publications selected were scientific articles (93.7\%), whereas there were some letters, practical guides, and theoretical reflections. Most of the scientific articles were observational studies (75.4\%), with fewer literature reviews (12.7\%) and experimental studies (5.6\%).

The interest on this topic predominated in America (54.4\%), with half of the publications coming from the United States (50\%), followed by Canada (4.0\%). Europe was the second continent with the most publications (26.6\%), in which the United Kingdom stood out (7.9\%), followed by Switzerland (2.4\%). Australia stood out in Oceania; India, in Asia (both with $3.2 \%$ ); and Tanzania, in Africa (2.0\%).

The most investigated age group was adolescence (46.5\%), and the most frequent sample size ranged from 101 to 500 participants (32.5\%). 
Table 1 - General characteristics of the articles included in the scoping review $(n=252)$.

\begin{tabular}{|c|c|c|}
\hline Characteristic & Number $(\mathrm{n}=252)$ & Percentage $(\%)$ \\
\hline \multicolumn{3}{|l|}{ Publication year } \\
\hline $2010-2014$ & 94 & 37.3 \\
\hline $2015-2019$ & 156 & 61.9 \\
\hline August 2020 & 2 & 0.8 \\
\hline \multicolumn{3}{|l|}{ Publication type } \\
\hline Article & 236 & 93.6 \\
\hline Reflection & 6 & 2.4 \\
\hline Guideline & 5 & 2 \\
\hline Letter & 5 & 2 \\
\hline \multicolumn{3}{|l|}{ Age range } \\
\hline$\leq 10$ & 36 & 14.3 \\
\hline 10 to 19 & 117 & 46.5 \\
\hline 19 to 24 & 60 & 23.8 \\
\hline Not informed & 39 & 15.5 \\
\hline \multicolumn{3}{|l|}{ Sample size } \\
\hline$\leq 100$ & 70 & 27.8 \\
\hline 101 to 500 & 82 & 32.5 \\
\hline 501 to 1000 & 18 & 7.1 \\
\hline$>1000$ & 29 & 11.5 \\
\hline Not informed/not applicable & 53 & 21 \\
\hline
\end{tabular}

Source: Authors.

The keywords and health topics approached in the publications were represented in word clouds and analyzed with a word count (Figure 2). The words "child", "children", "adolescent", and "youth" were excluded from both because they are the target population of the study. The most recurrent and frequent keywords include "care", used 125 times (7.3\%) and "health", 102 times (6.0\%), followed by "foster" (4.6\%), "welfare" (3.2\%), "mental" (2.6\%), and "maltreatment" (1.9\%).

Both the individual words and the sum of separate words were considered for the health topics, according to the word count analysis. The most recurrent topic was "mental health problems", approached 293 times (16\%), followed by "physical status", 150 times (8.2\%), and third, "risk maltreatment", 71 times (3.9\%). Other topics were "emotional needs" (2.2\%), "factors oral", referring to the factors influencing their oral health status (2.0\%), "quality of placements" (1.9\%), "social life" (1.8\%), "behavioral symptoms" (1.6\%), "abuse" $(0.9 \%)$, "services", referring to health service use $(0.8 \%)$, and "sexual", approached 13 times $(0.7 \%)$. 
Figure 2 - Word clouds with the recurrence of keywords (a) and health topics (b) observed in the studies.

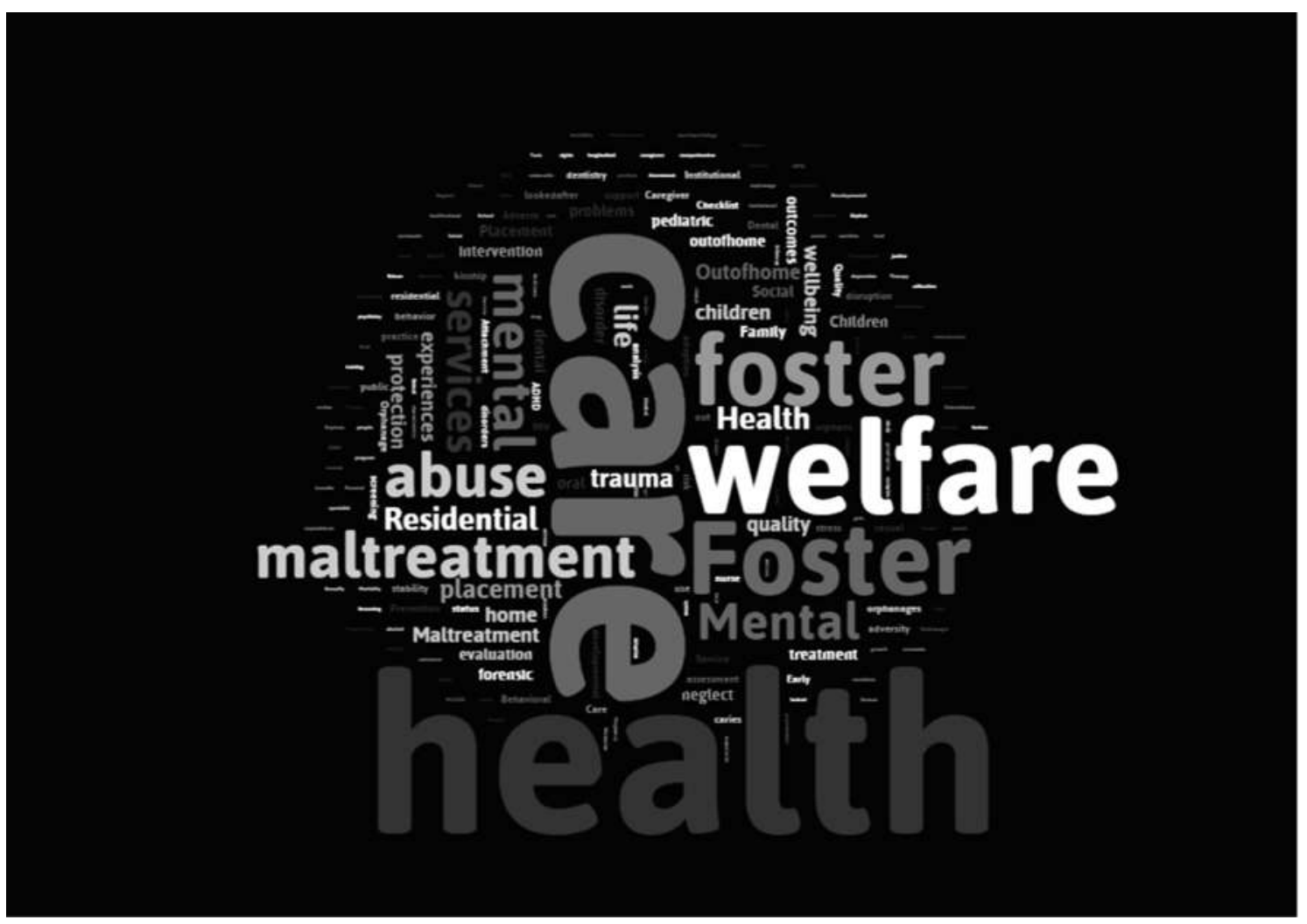

(a)

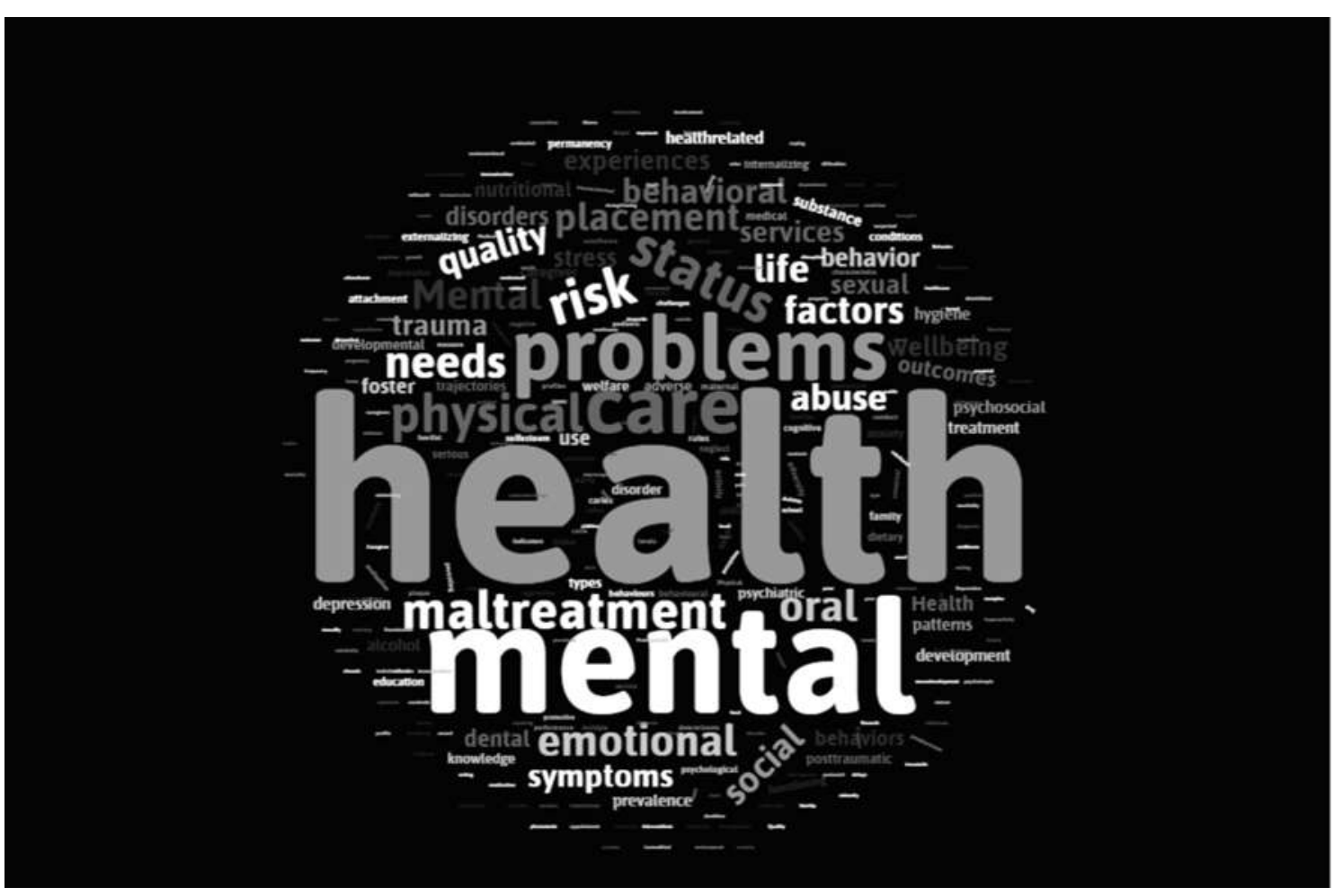

(b)

Source: Reproduced with the Word Cloud program.

Regarding the field of knowledge, most of the publications were from the Health Sciences (81.8\%), 81 of which were 
interdisciplinary, involving more than one subfield of health. Multidisciplinary studies, involving both the Health and Social Sciences (18.2\%), and the Human Science studies (13.1\%) came next. We identified the following subfields in the Health Sciences: Medicine, Dentistry (4.8\%), Public Health (3.2\%), Nursing (2.4\%), Nutrition (2.0\%), and Pharmacy (0.4\%). In the Human Sciences, we found Psychology (13.1\%). In Medicine, we identified Pediatrics (14.7\%), Psychiatry (8.3\%), Endocrinology (0.4\%), and Parasitology (0.4\%).

The distribution of publications per year according to the field of study is shown in Chart 1 , considering both the publications with different subfields of health (interdisciplinary) and the ones integrating the Health and Social Sciences (multidisciplinary).

Chart 1. Bubble chart with the interdisciplinary and multidisciplinary fields and subfields of the publications per year*.

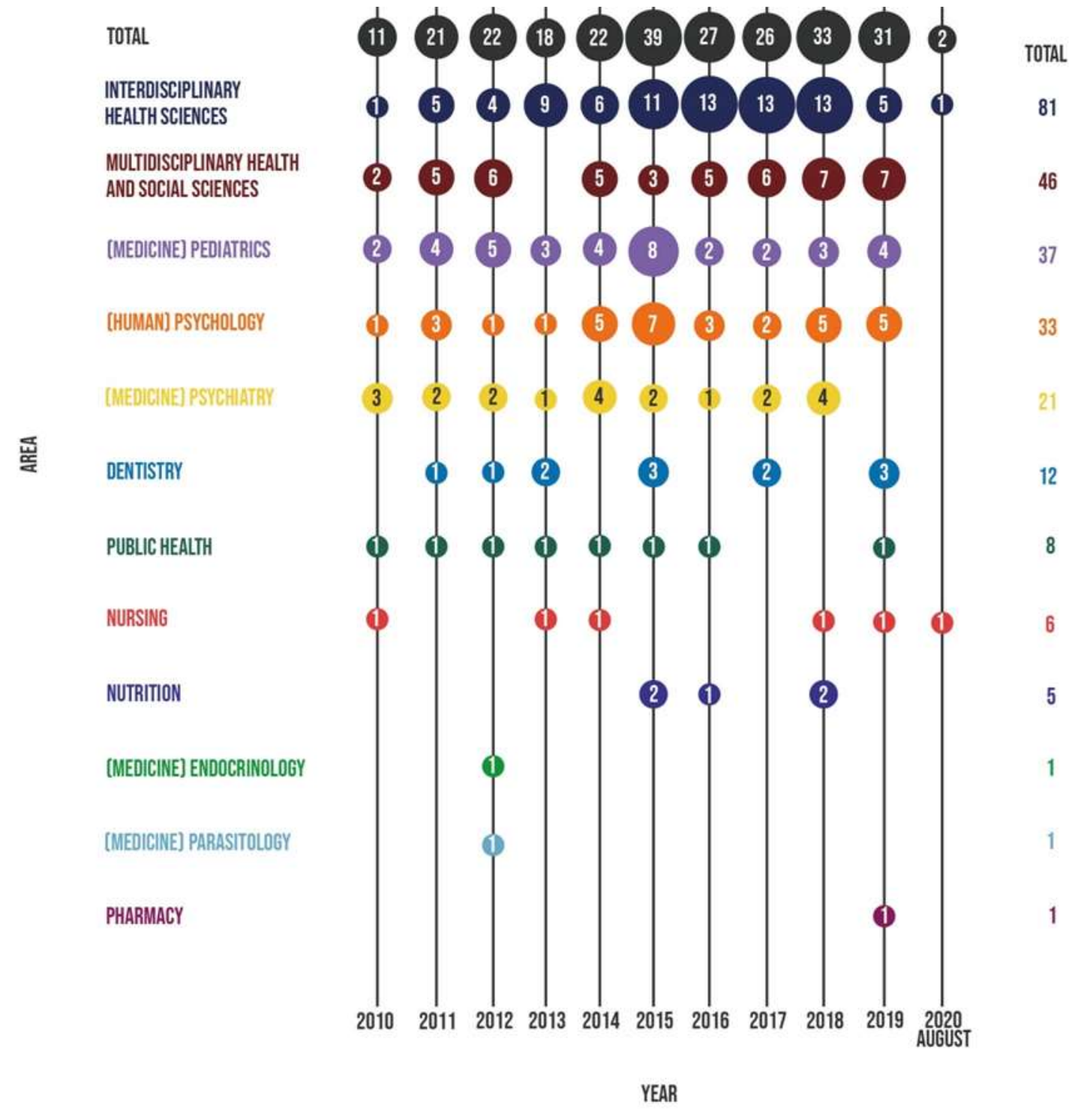

* Publications encompassed in the Interdisciplinary Health Sciences approached different fields of health, whereas those in the Multidisciplinary Health and Social Sciences approached fields of health integrated with fields of the Social Sciences. Source: Authors.

The analysis of types of institutional care revealed a predominance of foster care $(40.1 \%)$, child welfare system (11.9\%), out-of-home care (11.5\%), orphanage (10.7\%), kinship care (8.3\%), residential care (7.1\%), children's home (3.6\%), institutions (3.6\%), and others (19\%). There was a significant association between the types of foster care and the continents 
analyzed in the publications $(\mathrm{p}<0.05)($ Chart 2). No association was found for kinship care or residential care.

Chart 2. Assessment of the types of foster care per continent (articles assessed: $\mathrm{N}=252$ ).

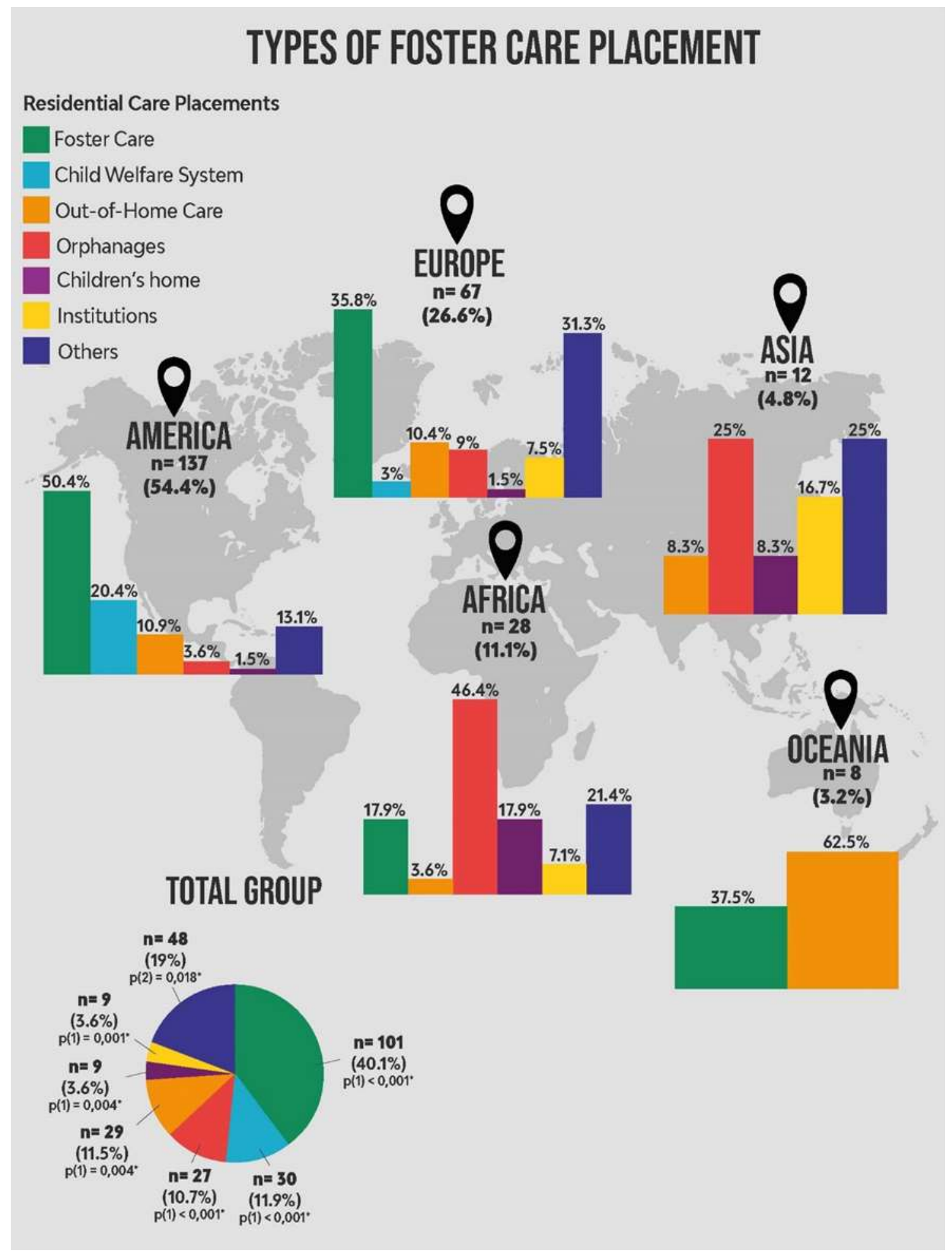

Caption: Calculated with (1) Fisher's Exact test; (2) Pearson's chi-square test. Source: Authors.

\section{Discussion}

This century has witnessed a sharp increase in the number of institutionalized children and adolescents (Mohammadzadeh, Awang, Ismail, \& Shahar, 2019) which may explain the increase in the number of publications between 
2010 and 2019. We did not cover 2020 in this analysis because we lacked full-year data, resulting in a small sample. Moreover, this specific number may be explained by the disruptive time experienced worldwide in 2020 due to the COVID-19 pandemic.

Half of the publications we retrieved were from the United States, whose demographic data estimate that approximately 1 out of every 170 children in the country are in foster care (Carabez \& Kim, 2019). Interestingly, no Brazilian paper was identified with the search strategy we used. This demonstrates the infrequent scientific look to this vulnerable and unassisted portion of our country's population. The studies have rather emphasized the foster process and the impact on the various aspects of family disruption concerning the various changes that took place in the last decades (Barbosa, Antunes, \& Padilha, 2016; Moré \& Sperancetta, 2010; Silva \& Arpini, 2013).

In the fields of knowledge, there was a predominance of the Health Sciences. The Social Sciences participated in multidisciplinary studies, and the Human Sciences were represented by Psychology papers. They reveal the importance of children and adolescents in foster care and their health status to the different fields of knowledge. As for the subfields in relation to time, Pediatrics, Psychology/Psychiatry, and Dentistry had increasing participation in the publications about children and adolescents in foster care.

Most of the studies approached children and adolescents in foster care or the child welfare system. In contrast, up to the 1980s, children were placed almost exclusively in institutions for children, until new laws provided the possibility of foster care - which is currently preferable, particularly in the case of smaller children (López, Del Valle, Montserrat, \& Bravo, 2011). Care provided in a home is broadly recognized as the most adequate in most cases, including the care given by relatives or social workers. Since the second half of the 20th century, academic and clinical research have reported the negative effects of institutionalization (Ainsworth \& Thoburn, 2014), and in the last 10 years, institutions and orphanages seldom appear as forms of placement.

The present study observed that the different types of foster care services throughout the world had an association with the continents, which reflected the paradigm shift from institutionalization to home foster care. This trend was observed in developed countries, whereas in African and Asian countries, orphanages still predominate. This agrees with the literature, which reports that large, usually philanthropic institutions are commonly found in those regions, due to their extreme poverty and other adversities (Delap, 2011). Hence, there are inequalities between the continents, which may be economic, social, cultural, or historical.

The mental health problems were the most frequent of the health topics approached in the publications. They were present in intervention studies based on youth life skills (Mohammadzadeh et al., 2019), different youth development programs, mentorships (Heather et al., 2019), and coping methods (Mohammadzadeh, Tajik, Awang, \& Latiff, 2018) to improve emotional health (post-traumatic stress symptoms, dissociative symptoms) and self-esteem. The parents and/or adoptive caregivers had a remarkable participation in these studies, both providing information about the young people and being themselves the target population. Also, we found review studies on mental health in institutional care systems (Naylor et al., 2019), with a prevalence of stress, anxiety, and depression symptoms associated with a history of abuse, negligence, maltreatments - which were very frequently cited in the present study, as well (Dhakal et al., 2019; McGuire et al., 2018; Tordön et al, 2018). Moreover, the literature consistently points out this population's vulnerability and propensity to countless health risks. Studies from the last 30 years show that children in foster care have more development and physical, mental, and oral health problems than the child population in general) (Deutsch \& Fortin, 2015; Rienk, Phillips, McCrae, Bender, \& Brown, 2017; Szilagyi, 2012; Szilagyi, Rosen, Rubin, \& Zlotnik, 2015).

Health service needs and physical status also received special attention. A scoping review aimed to identify the knowledge of health records from children in care (Thompson \& Lau, 2013). Also, in a public health study on the role of nursing in addressing child healthcare needs, the nurses reported that the most important ones were the mental and emotional 
health services, self-esteem/self-value, and dental care (Carabez \& Kim, 2019). The oral health conditions were surveyed along with the reported need for dental services (Ehlers et al., 2019). Also, a study opportunely assessed oral hygiene habits and the influence of the perception of rejection and the social determinants on children in foster care, comparing them with others who lived with their parents (Ramos-Morcillo, Moreno-Martínez, Susarte, Hueso-Montoro, \& Ruzafa-Martínez, 2019).

Lastly, we highlight that the data presented here must be interpreted considering the limitations of this type of study. Hence, the level of evidence of the studies in the review was not measured, following the scoping review development guidelines (Peters et al., 2015). Likewise, the content of the publications is not analyzed in-depth.

\section{Conclusion}

In an exploratory approach, this scoping review aimed to identify the characteristics of scientific publications on the health of children and adolescents in foster care. Studies on mental, physical, and dental health were identified more frequently, with increasing participation of Pediatrics, Psychology/Psychiatry, and Dentistry through time. The multidisciplinary studies involving the Social and Health Sciences stood out, demonstrating the importance of foster care for children and adolescents and their health status to different fields of knowledge.

We noticed different paradigms in the world regarding institutionalization. Home foster care is predominant in the developed countries, whereas in continents that have to cope with extreme poverty, the system is still based on large institutions. Thus, there is a need for individualized public assistance and care policies in different parts of the world. In-depth research on the topics of health observed here is warranted.

\section{References}

Ainsworth, F., \& Thoburn, J. (2014). An exploration of the differential usage of residential childcare across national boundaries. Int J Soc Welf, 23 , 16-24.

Almquist, Y. B., Jackisch, J., Forsman, H., Gauffin, K., Vinnerljung, B., \& Hjern, A. (2018). A decade lost: does educational success mitigate the increased risks of premature death among children with experience of out-of-home care? J Epidemiol Community Health, 72, $997-1002$.

Barbosa, V. M. C., Antunes, M. C., \& Padilha, M. G. S. (2016). A reinserção familiar de crianças e adolescentes vítimas de violência intrafamiliar em acolhimento institucional por medida de proteção: o abuso sexual em foco. Bol./Acad. Paul. Psicol., 36(91), 286-309.

Carabez, R., \& Kim, J. E. (2019). PART I: The role of public health nursing in addressing health care needs of children in foster care. Public Health Nurs, 36(5), 702-708.

Casanueva, C., Stambaugh, L., Urato, M., Fraser, J. G., \& Williams, J. (2011). Lost in transition: Illicit substance use and services receipt among at-risk youth in the child welfare system. Child Youth Serv Rev, 33(10), 1939-1949.

Delap E. (2011). Scaling down: Reducing, reshaping and improving residential care around the world, positive care choices: Working paper 1. London: Everychild.

Deutsch, S. A., \& Fortin, K. (2015). Physical health problems and barriers to optimal health care among children in foster care. Curr Probl Pediatr Adolesc Health Care, 45(10), 286-291.

Dhakal, S., Niraula, S., Sharma, N. P., Sthapit, S., Bennett, E., Vaswani, A., \& Lau, J. Y. (2019). History of abuse and neglect and their associations with mental health in rescued child labourers in Nepal. Aust N Z J Psychiatry, 53(12), 1199-1207.

Ehlers, V., Callaway, A., Wantzen, S., Patyna, M., Deschner, J., \& Azrak, B. (2019). Oral health of children and adolescents with or without attention deficit hyperactivity disorder (ADHD) living in residential care in rural Rhineland-Palatinate, Germany. BMC Oral Health, $19(1), 258$.

Foxcroft, D. R., \& Tsertsvadze, A. (2011). Universal school based prevention programs for alcohol misuse in young people. Cochrane Database Syst Rev, (5), CD009113.

Gabrielli, J., Jackson, Y., \& Brown, S. (2016). Associations between maltreatment history and severity of substance use behavior in youth in foster care. Child Maltreat, 21(4), 298-307.

Gander, T., Boonmann, C., Fegert, J. M., Kölch, M., Schmeck, K., Di Gallo, A., \& Schmid, M. (2019). Predictive factors for changes in quality of life among children and adolescents in youth welfare institutions. Soc Psychiatry Psychiatr Epidemiol, 54(12), 1575-1586.

Greger, H. K., Myhre, A. K., Lydersen, S., \& Jozefak, T. (2015). Previous maltreatment and present mental health in a high-risk adolescent population. Child Abuse Negl, 45, 122-134. 
Heather, N. T., Weiler, L. M., Garrido, E. F., Rhodes, T., Boat, A., \& Fadell, M. (2019). A positive youth development approach to improving mental health outcomes for maltreated children in foster care: Replication and extension of an RCT of the Fostering Healthy Futures Program. Am J Community Psychol, 64(3-4), 405-417.

Human Rights Watch (HRW). (2014). Without Dreams Children in Alternative Care in Japan. Human Rights Watch.

Joanna Briggs Institute (JBI). (2015). The Joanna Briggs Institute reviewers' manual 2015: methodology for JBI scoping reviews. Adelaide: Joanna Briggs Institute.

López, M., Del Valle, J. F., Montserrat, C., \& Bravo, A. (2011). Factors affecting foster care breakdown in Spain. Span J Psychol, 14(1), 111-122.

Mcguire, A., Cho, B., Huffhines, L., Gusler, S., Brown, S., \& Jackson, Y. (2018). The relation between dimensions of maltreatment, placement instability, and mental health among youth in foster care. Child Abuse Negl, 86, 10-21.

Mohammadzadeh, M., Awang, H., Ismai,1, S., \& Shahar, H. K. (2019). Improving emotional health and self-esteem of Malaysian adolescents living in orphanages through Life Skills Education program: A multi-centre randomized control trial. Plos ONE, 14(12), e0226333.

Mohammadzadeh, M., Tajik, E., Awang, H., Latiff, L. A. (2018). Emotional health and coping mechanisms among adolescents in Malaysian residential foster care homes: A comparative study with adolescents living with families. Asian J Psychiatr, 32, 156-158.

Moré, C. L. O., \& Sperancetta, A. (2010). Práticas de pais sociais em instituições de acolhimento de crianças e adolescentes. Psicol Soc, 22(3), 519-528.

Naylor, M. W., Wakefield, S. M., Morgan, W., \& Aneja, A. (2019). Depression in children and adolescents involved in the child welfare system. Child Adolesc Psychiatr Clin N Am, 28(3), 303-314.

Peters, M. D., Godfrey, C. M., Khalil, H., mcinerney, P., Parker, D., \& Soares, C. B. (2015). Guidance for conducting systematic scoping reviews. Int J Evid Based Healthc, 13(3), 141-146.

Ramos-Morcillo, A. J., Moreno-Martínez, F. J., Susarte, A. M. H., Hueso-Montoro, C., \& Ruzafa-Martínez, M. (2019). Social Determinants of Health, the Family, and Children's Personal Hygiene: A Comparative Study. Int. J. Environ. Res. Public Health, 16(23), 4713.

Rienks, S., Phillips, J., mccrae, J., Bender, K., \& Brown, S. (2017). Complex health concerns among child welfare populations and the benefit of pediatric medical homes. Child Abuse Negl, 65, 212-225.

Silva, M. L., \& Arpini, D. M. (2013). A nova lei nacional de adoção: desafios para a reinserção familiar. Psicol Estud, 18(1), 125-135.

Szilagyi, M. (2012). The pediatric role in the care of children in foster and kinship care. Pediatr Rev, 33(11), $496-508$.

Szilagyi, M., Rosen, D. S., Rubin, D., \& Zlotnik, S. (2015). Health care issues for children and adolescents in foster care and kinship care. Pediatrics, 136(4), e1131-e1140.

Thompson, C., \& Lau, F. Y. (2013). A scoping review on health records for child-in-care. Stud Health Technol Inform, 183, 43-48.

Tordön, R., Svedin, C. G., Fredlund, C., Jonsson, L., Priebe, G., \& Sydsjö, G. (2018). Background, experience of abuse, and mental health among adolescents in out-of-home care: a cross-sectional study of a Swedish high school national sample. Nord J Psychiatry, 73(1), 1-8.

Tricco, A. C., Lillie, E., Zarin, W., O'Brien, K. K., Colquhoun, H., Levac, D., \& Straus, S. E. (2018). PRISMA Extension for Scoping Reviews (PRISMA-scr): Checklist and explanation. Ann Intern Med, 169(7), 467-473.

UNICEF, \& Eastern Europe and the Commonwealth of Independent States (CEE/CIS). (2010). At home or in a home? Formal care and adoption of children in Eastern Europe and Central Asia. Geneva: UNICEF, CEE/CIS.

UNICEF. Orphans. (2017). Unicef Press Center.

Wolkind, S., \& Rutter, M. (1973). Children who have been "in care": an epidemiological study. J Child Psychol Psyc, 14(2), 97-105. 